American Journal of Applied Sciences 4 (10): 786-791, 2007

ISSN 1546-9239

(C) 2007 Science Publications

\title{
Compressibility Behavior of Tropical Peat Reinforced with Cement Columns
}

\author{
${ }^{1}$ Youventharan Duraisamy, ${ }^{2}$ Bujang B.K. Huat and ${ }^{2}$ Azlan A. Aziz \\ ${ }^{1}$ University Malaysia Pahang, Malaysia \\ ${ }^{2}$ University Putra Malaysia, Serdang, Selangor, Malaysia
}

\begin{abstract}
This paper presents the compressibility of tropical peat reinforced with cylindrical cement columns. When a cement column is installed vertically in peat, its compressibility is reduced because of the hardened skeleton matrix formed by cement particles bonding with adjacent soil particles in the presence of pore water. The effects of the cement column diameter on the compressibility have been investigated in this study. The results indicated that compressibility index $C_{c}$ and $C_{\alpha}$ decreased with increasing diameter of the cement column. Specimens with $45 \mathrm{~mm}$ (area ratio $=0.09$ ) diameter and $60 \mathrm{~mm}$ (area ratio $=0.16$ ) diameter of single cement column were cured for 7, 14 and 28 days, after which they were subjected to Rowe Cell Consolidation test. Results are also presented from test conducted on groups of cement columns using four (area ratio $=0.04$ ) and nine (area ratio $=0.09$ ) columns of $15 \mathrm{~mm}$ diameter each to investigate the influence of number of cement columns on compressibility of peat soil. Based on the results obtained, it shows that cement columns can successfully reduce the compressibility of tropical peat.
\end{abstract}

Keywords: Cement columns, deep soil mixing, organic soil, peat soil, Rowe Cell consolidation.

\section{INTRODUCTION}

Peat represents the extreme form of soft soil. It is an organic soil which consists more than $70 \%$ of organic matters. Peat deposits are found where conditions are favorable for their formation. In Malaysia, some 3 million hectares of land is covered with peat. While in Indonesia peat covers about 26 million hectares of the country land area. Two third of the world coverage of tropical peat are in South East Asia. Since the coverage of peat soil is quite extensive, utilization of these marginal soil are required in the recent years. Hence suitable geotechnical design parameters and construction techniques needed for this type of ground condition. Peat poses serious problems in construction due to its longterm consolidation settlements even when subjected to a moderate load ${ }^{[1]}$. Hence, peat is considered unsuitable for supporting foundations in its natural state. Various construction techniques have been carried out to support embankments over peat deposits without risking bearing failures but settlement of these embankments remains excessively large and continues for many years. Besides settlement, stability problems during construction such as localized bearing failures and slip failures need to be considered.
Experimental Design and Laboratory Work: The main objective of this research is to find out the effect of cement column on compressibility when installed in tropical peat soil. Apart from that researcher is also interested to examine the peculiar engineering behavior of tropical peat with respect to their compressibility characteristics due to variation in fiber content and organic content. Meanwhile the index properties such as natural water content, organic content, liquid limit, specific gravity and density of various type of tropical peat were obtained to establish suitable correlation. Understanding the engineering properties and compressibility characteristics of peat will give hand for engineers in determining suitable ground improvement method. Thus, proper construction and foundation design guide for various type of peat could be outlined for future developments in peat ground.

Sample Preparation: Undisturbed samples of peat soil were taken from three different locations in Banting (located on the West coast of Peninsular Malaysia) by using a sampling tube. A suitable auger was designed and fabricated to collect undisturbed peat samples as shown in Fig. 1. The handle was formed of a $60 \mathrm{~cm}$ cross bar and the stem of $100 \mathrm{~cm}$ height. The cylindrical tube is $150 \mathrm{~mm}$ (internal) in diameter. The upper part of the cy-

Corresponding Author: Bujang B.K. Huat, Faculty of Engineering, Universiti Putra Malaysia, 43000 Serdang Selangor. Tel: 603-89466368, Fax: 603-86567129 
lindrical hollow body is fitted with a cover plate. Meanwhile the lower part of the cylindrical tube was sharpened to cut roots as the auger is slowly rotated into the peat ground during sampling. The thin tube was fitted with a valve which is left open during sampling to release both air and water pressure. The valve is then closed prior to withdrawal of the tube with the peat sample enclosed, thus providing a vacuum effect to help the sample in place. Soon after the sampler is withdrawn the cylindrical tube was sealed with paraffin wax. Once in the laboratory, the top cover on the cylindrical tube was opened to extract the sample into the Rowe Cell. This sampler is suitable for sampling peat soil up to depth of about $1 \mathrm{~m}$ only. The auger enables the extraction of peat core sample of $150 \mathrm{~mm}$ diameter by $230 \mathrm{~mm}$ length. The top and bottom of the specimen was trimmed. Fibrous soil such as peat is easily disturbed therefore the trimming process was carried out carefully. Furthermore, the trimming process was carried out quickly to minimize a change in the water content of the soil sample.

Sample was then tested using Rowe Cell to overcome most of the disadvantages of the conventional oedometer apparatus when performing consolidation tests on low permeability soils, including non uniform deposits. The most important features are the ability to control drainage and to measure pore water pressure during the course of consolidation tests. Fig. 2 shows the experimental set up of using Rowe Cell. This system is based on Rowe Cell consolidation cell and GDS pressure/volume controllers. Size of the cell used in this research was $150 \mathrm{~mm}$ in diameter and $50 \mathrm{~mm}$ in height. The hydraulic loading system pressure and vertical load can be applied to the sample surface either via a flexible diaphragm to give a uniformly distributed pressure (free strain) or via a rigid plate to give uniform settlement (equal strain). Rigid plate was used in the research as shown in Fig. 3. Back pressure of $200 \mathrm{kN} / \mathrm{m}^{2}$ was applied to the top drain of the cell so that the field hydraulic gradients can be modeled. The bottom drain is provided with a tapping to a pressure transducer.

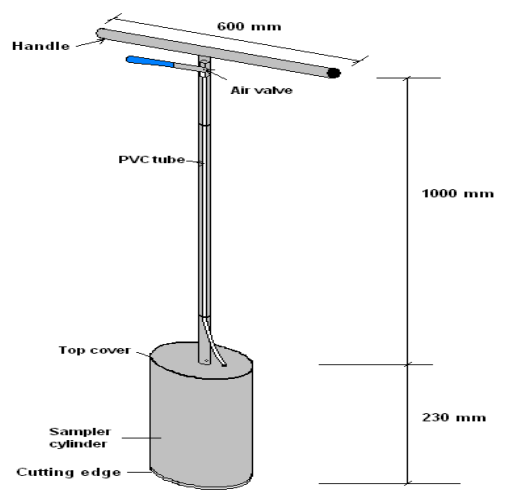

Fig. 1: UPM Peat sampler.

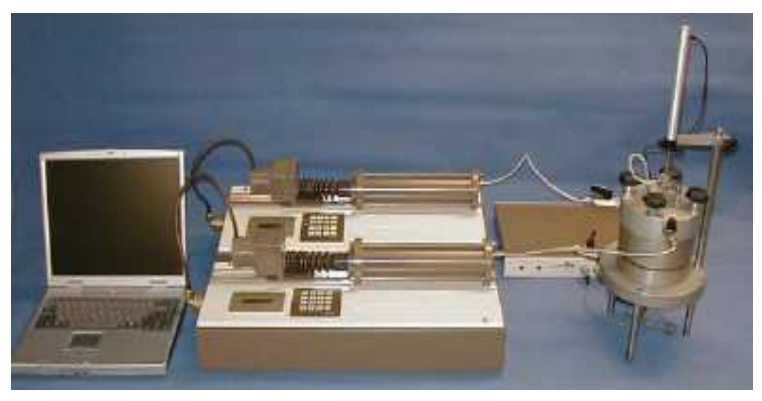

Fig. 2: The experimental set up of using Rowe Cell.

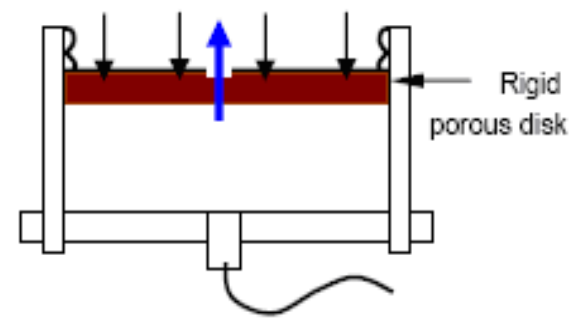

Fig. 3: Rigid plate to give equal strain.

To investigate the influence of diameter of columns, a single cement column was placed at the center of the cell containing peat sample. A portion of the peat soil was taken out from the cell using a PVC tube and replaced with dry cement powder to form the cement column as shown in Fig. 4(a). The diameter of the cement column was $45 \mathrm{~mm}$ (area ratio $=0.09$ ) and $60 \mathrm{~mm}$ (area ratio $=0.16)$. The samples were cured for 7,14 and 28 days in a soaking basin as shown in Fig. 4(b). After the curing days, Rowe Cell Consolidation test was carried out on the samples consecutively. Meanwhile group columns of four (area ratio $=0.04$ ) and nine (area ratio $=$ 0.09 ) cement columns were formed using $15 \mathrm{~mm}$ diameter PVC pipe at the spacing of $2 \mathrm{~d}$ ( 2 times the value of column diameter) to investigate the influence of group cement columns in reducing compressibility of peat soil.
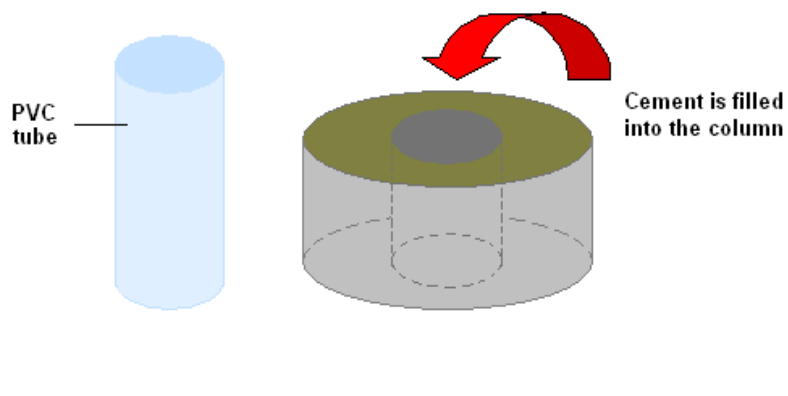

(a) 
Am. J. Applied Sci., 4 (10): 786-791, 2007

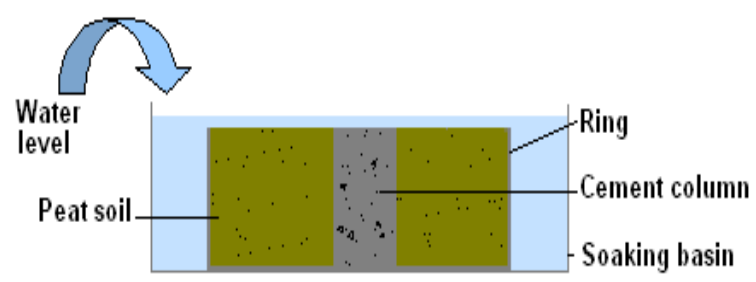

(b)

Fig. 4:(a) Method used to form cement column and (b) method used to cure peat-cement column sample.

Load increment was applied at 20,40,80, 160, and $320 \mathrm{kN} / \mathrm{m}^{2}$. Additional load was placed on the soil specimen to determine the soil behavior at higher pressure. Each load increment was maintained for 24 hours. The test started with a vertical load of $20 \mathrm{kN} / \mathrm{m}^{2}$ and deformation transducer readings with corresponding time observations were recorded using data logger which is connected to computer. The load was maintained for 24 hours. After 24 hours, the same procedure was repeated with different applied load. Time-deformation graphs were plotted and settlements were determined using GDSLAB control and acquisition software.

Testing programs: Index properties of peat soil used in the classification system of peat namely the water content, organic content, specific gravity, fiber content, degree of humification and Atterberg limits were determined based on test procedures according to the British Standard BS1377: 1990, 'Methods of test for soils for civil engineering purposes'. Apart from the classifying tests, compressibility behavior of the peat soil was determined by Rowe Cell consolidation test for both the natural (untreated) and cement column installed peat samples.

\section{RESULTS AND DISCUSSION}

One of the main objectives of this study is to find the relationship between the basic geotechnical properties of peat soil with index parameters such as natural water content, organic content and liquid limit. It must also be appreciated that compared with soils of mineral origin, the peat soils, in particular those of the tropical genesis, have only recently been given attention. As such even determination methods of some of the basic properties are still being researched. In some cases no consensus has been reached, either with respects to the methods, nor details of any given methods. However, for ease of comparison, the apparently most commonly used methods of determination of soil basic properties are used in this study.

Soil description: Peat sample was obtained from marine and continental deposits on the West coast of Peninsular Malaysia. It consists primarily of low plasticity fines, some fine to medium sands and it is dark brown in color. Based on results of characterization tests performed it ranges from three different types of peat according to the USDA classification system and Von Post Scale. Soil classification tests were performed on each soil sample in accordance with accepted BS 1377: 1990 and ASTM ranges. The results of the characterization tests are in Table 1. The Atterberg limits were determined on the soil particles passing the $475 \mu \mathrm{m}$ sieve.

As seen in Table 1, fairly significant increase in liquid limit with the increase in natural water content. Huat $^{[2]}$ stated that the natural water content of peat in West Malaysia ranges from $200 \%$ to $700 \%$ and with organic content in the range of $50 \%$ to $95 \%$. The recorded values in the above table fulfill this statement. Further more the liquid limit was in the range of $200 \%$ to $500 \%$ as reported by Huat ${ }^{[2]}$. Engineering properties such as specific gravity, dry density and bulk density of the samples were within the range as reported by Huat ${ }^{[2]}$.

Compressibility parameters: The following section presents the results of consolidation parameters using Conventional Oedometer test and Rowe Cell Consolidation test on natural (untreated) peat samples. Study was focused on two consolidation parameters which are Compression Index $(C c)$ and Coefficient of Secondary Compression $(C \alpha)$. Three types of peat which are fibric, hemic and sapric peat were used in the research.

Compression index, $\boldsymbol{C c}$ : Based on Fig. 5, the compression index $(C c)$ values from Rowe Cell consolidation test for the natural fibric peat were within the range of 1.878 to 3.627 for consolidation pressure of $40 \mathrm{kPa}$ to $320 \mathrm{kPa}$. Values of $C c$ for hemic peat were recorded as 1.34 to 2.99 and sapric peat was 1.24 to 2.63.These values were from Rowe Cell consolidation test and measured higher than the values from conventional oedometer test results. Results from conventional oedometer test were far less reliable because back pressure was not induced and pore water pressure was not measured during the course of the test. The compression index $(C c)$ values from oedometer test for fibric peat was 1.453 to 3.211 , hemic was 1.29 to 2.78 and sapric was 1.15 to 2.44. However these values are far smaller than what has 
been reported for peat as 5 to 10 in the literature. Regardless of type of peat, samples collected from this tropical region possess high compressibility when subjected to higher loading over the time period.

Coefficient of secondary compression, $C \alpha$ : Based on Fig. 6, the coefficient of secondary compression $(C \alpha)$ values from Rowe Cell consolidation test for the natural (untreated) fibric peat was within the range of 0.0608 to 0.0985 for consolidation pressure of $40 \mathrm{kPa}$ to $320 \mathrm{kPa}$. Values of $C \alpha$ for hemic peat were recorded as 0.0585 to 0.0959 and sapric peat was 0.0544 to 0.0939 . These values were from Rowe Cell consolidation test and measured higher than the values from conventional oedometer test results. The coefficient of secondary compression $(C \alpha)$ value from oedometer test for fibric peat was 0.0374 to 0.0901 , hemic was 0.0225 to 0.0881 and sapric was 0.014 to 0.0851 .

According to $\mathrm{Mesri}^{[3]}$, soil with $\mathrm{C} \alpha$ values of more than 0.064 is classified as soil with extremely high secondary compressibility. The coefficient of secondary compression $C \alpha(=\Delta e / \Delta \log t)$ was determined from the slope of the $e-\log t$ curves during the period of 4 to 24 hours after load increment, assuming that the secondary compression would have started 4 hours after loading. The variation of $C \alpha$ with applied consolidation pressure can be seen in Fig. 6. The $C \alpha$ increases as the consolidation pressure is increased. Similar trend was observed with samples tested using oedometer. Thus peat samples used in this research will cause high secondary settlements with the increase in loading over the time period.

Compression ratio: Parameter $\mathrm{C}_{\mathrm{C}} / 1+\mathrm{e}_{\mathrm{o}}$ is called compression ratio. According to O'Loughlin and Lehane ${ }^{[4]}$, compression ratio for peat in the range of 0 to 0.05 is classified as very slightly compressible followed by slightly compressible for anything in between 0.05 to 0.10 . Moderately compressible peat lies in the range of 0.10 to 0.20 and very compressible peat has ratio in between 0.20 to 0.35 . Based on the compression ratios given in Table 2, all the three type of tropical peat regardless of type of test used was classified as very compressible $(>0.20)$.

Law of compressibility: Mesri and Castro ${ }^{[5]}$ reported that the value of $C \alpha / C c$ law for peat and muskeg lies in the range of 0.05 to 0.07 . Based on Table 2, value of $\mathrm{C} \alpha / C \mathrm{C}$ law for tropical peat determined from conventional oedometer test was about 0.027 for fibric, hemic and sapric. Whereas samples tested using Rowe Cell consolidation was recorded in the range of 0.02 to 0.04 . These values are generally not in agreement with the values reported in literature. Since the value of $C \alpha / C c$ law for tropical peat is lower than the value of $C \alpha / C c$ law reported in the literature, less creep settlement develops when the tropical peat is loaded. However, this need to be verified with further research works involving

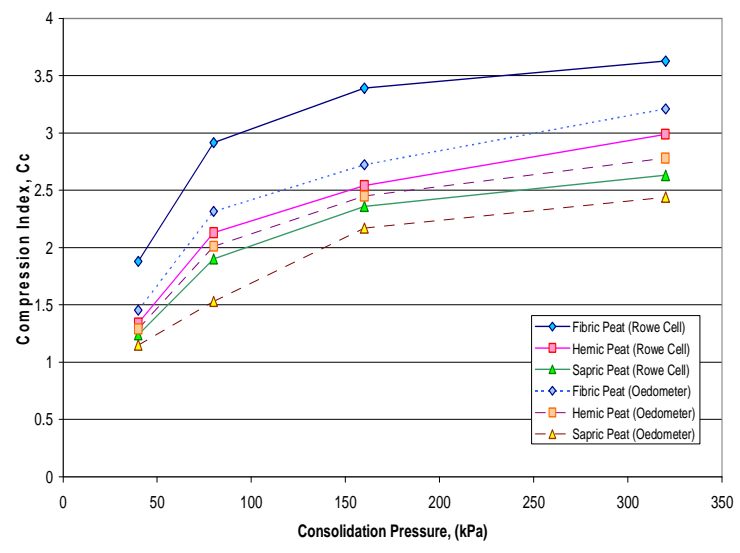

Fig. 5: Compression index versus consolidation pressure.

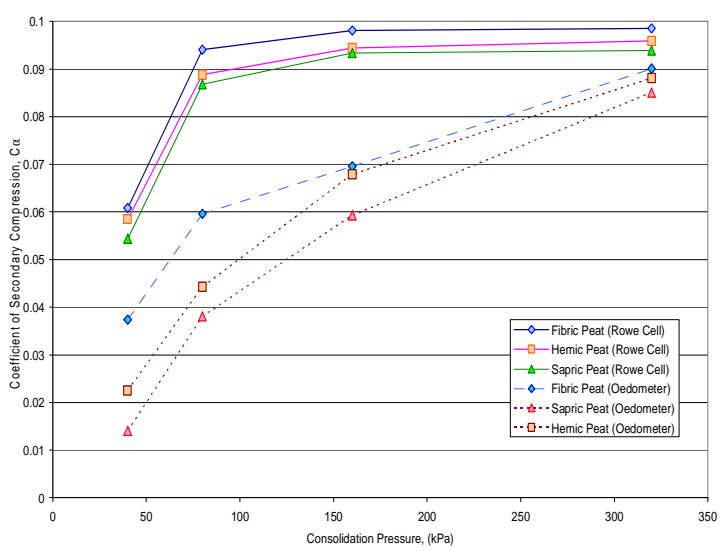

Fig. 6: Coefficient of secondary compression versus consolidation pressure

long-term consolidation test. A parametric study was conducted assuming a normally consolidated $5 \mathrm{~m}$ depth peat ground with embankment. Using one dimensional consolidation theory and Anglo Saxon method, ultimate consolidation settlements were predicted as in Table 2. Based on the results obtained, it shows that fibric peat recorded the highest settlements followed by hemic and sapric. 
Am. J. Applied Sci., 4 (10): 786-791, 2007

Table 1: Index properties of peat samples

\begin{tabular}{cllllllllll}
\hline BH & $\begin{array}{l}\text { Water Con- } \\
\text { tent }(\%)\end{array}$ & $\begin{array}{l}\text { Liquid } \\
\text { Limit } \\
(\%)\end{array}$ & $\begin{array}{l}\text { Organic } \\
\text { Content } \\
(\%)\end{array}$ & $\begin{array}{l}\text { Von } \\
\text { Post } \\
\text { Scale }\end{array}$ & $\begin{array}{l}\text { Fiber } \\
\text { Content } \\
(\%)\end{array}$ & $\begin{array}{l}\text { Specific } \\
\text { Gravity }\end{array}$ & $\begin{array}{l}\text { Void } \\
\text { ratio, } \\
\mathrm{e}\end{array}$ & $\begin{array}{l}\text { Dry } \\
\text { Density, } \\
\left(\mathrm{Mg} / \mathrm{m}^{3}\right)\end{array}$ & $\begin{array}{l}\text { Bulk } \\
\text { Density, } \\
\left(\mathrm{Mg} / \mathrm{m}^{3}\right)\end{array}$ & $\begin{array}{l}\text { Peat } \\
\text { Type }\end{array}$ \\
\hline 1 & 266 & 285 & 76 & $\mathrm{H} 5$ & 65 & 1.52 & 7.541 & 0.170 & 0.922 & Hemic \\
2 & 330 & 350 & 84 & $\mathrm{H} 4$ & 75 & 1.45 & 9.535 & 0.147 & 0.834 & Fibric \\
3 & 350 & 398 & 88 & $\mathrm{H} 4$ & 77 & 1.42 & 10.48 & 0.136 & 0.811 & Fibric \\
4 & 181 & 250 & 73 & $\mathrm{H} 7$ & 55 & 1.55 & 5.522 & 0.238 & 1.008 & Hemic \\
5 & 241 & 275 & 75 & $\mathrm{H} 6$ & 58 & 1.53 & 6.536 & 0.192 & 0.856 & Hemic \\
6 & 140 & 240 & 70 & $\mathrm{H} 8$ & 32 & 1.56 & 4.125 & 0.283 & 1.019 & Sapric \\
7 & 286 & 310 & 77 & $\mathrm{H} 5$ & 68 & 1.51 & 7.895 & 0.170 & 0.956 & Fibric \\
8 & 300 & 330 & 80 & $\mathrm{H} 8$ & 31 & 1.49 & 4.824 & 0.249 & 0.996 & Sapric \\
\hline
\end{tabular}

Table 2: Summary of compression parameters and predicted consolidation settlements

\begin{tabular}{cccccc}
\hline $\begin{array}{c}\text { Type of } \\
\text { Peat }\end{array}$ & $\begin{array}{c}\text { Compression } \\
\text { Index, } C_{C}\end{array}$ & $\begin{array}{c}\text { Compression } \\
\text { Ratio, } C_{C} /+e_{o}\end{array}$ & $\begin{array}{c}\text { Coefficient of } \\
\text { Secondary } \\
\text { Compression, } C \alpha\end{array}$ & $\begin{array}{c}\text { Law of } \\
\text { Compressibility, } \\
C \alpha / C c\end{array}$ & $\begin{array}{c}\text { Predicted } \\
\text { Consolidation } \\
\text { Settlements (m) }\end{array}$ \\
\hline Fibric & 2.752 & 0.422 & 0.0608 & 0.0283 & 2.32 \\
Hemic & 2.165 & 0.253 & 0.0585 & 0.0356 & 1.82 \\
Sapric & 1.935 & 0.217 & 0.0544 & 0.0380 & 1.63 \\
\hline
\end{tabular}

Effect of a single cement column: As for the main objective of this research, cement columns of two dimensions were prepared and installed in peat soils. Cement column with (45 mm diameter $\mathrm{x} 50 \mathrm{~mm}$ length) and (60 $\mathrm{mm} \times 50 \mathrm{~mm}$ length) were formed. They were cured for 7, 14 and 28 days to find out the factors influencing the performance of cement columns. Just as expected the cement columns cured for 28 days were proven to be more effective in reducing the compressibility parameters $C c$ and $C \alpha$ when tested using Rowe Cell Consolidation test. As shown in Fig. 7, single cement column with $60 \mathrm{~mm}$ diameter (area ratio $=0.16$ ) recorded the smallest values of $C c$ and $C a$ compared to $45 \mathrm{~mm}$ diameter (area ratio $=0.09)$ of cement column. A similar trend was observed among fibric, hemic and sapric peat.

Effect of a group of cement columns: A group of cement columns of diameter $15 \mathrm{~mm}$ each with a spacing of $2 \mathrm{~d}$ were used. Based on Fig. 7 when nine cement columns in the form of a $3 \times 3$ group tested, compressibility parameters were reduced more effectively than only four cement columns $(2 \times 2)$ used at the same spacing. This means that compressibility parameters decreased with an increasing number of cement columns in a group. Technically group of nine cement columns have larger area ratio of 0.09 compared to group of four cement columns with area ratio of 0.04 which influence the compressibility. Again the 28 days of curing time has significant impact on the final compressibility parameters values recorded. This pattern was similar in all the three type of peat which is fibric, hemic and sapric.

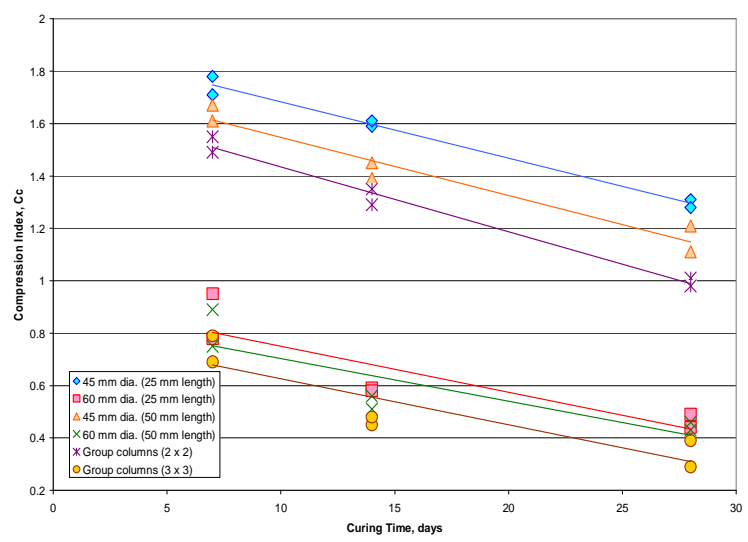

Fig. 7: Compression index versus curing time for various dimension of cement column.

Result implications: With the establishment of geotechnical database on index properties, primary and secondary compression of peat, a chart as in Fig. 8 was constructed for fibric peat. Data comprising of $C c$ and $C \alpha$ values from fibric peat sample with corresponding organic content were plotted in this chart. This chart is suitable as a design guide for engineers to determine settlements using two compressibility parameters $C c$ and $C \alpha$ while the organic content or liquid limit of sample is determined from simple laboratory test. This chart is only applicable for fibric type of peat with organic content more than $70 \%$ and fibric content more than 66 $\%$. 


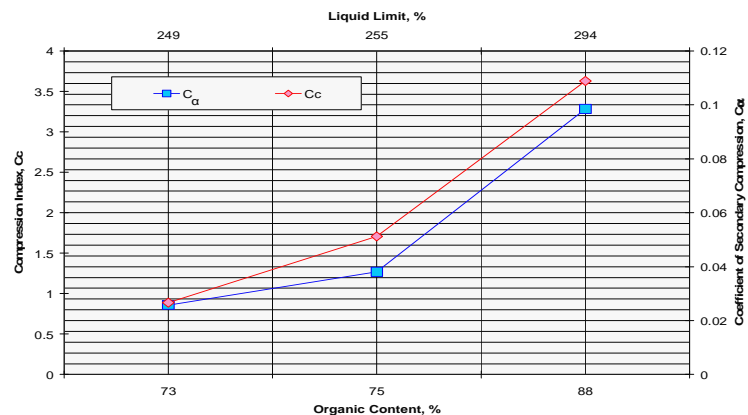

Fig. 8: Organic content (and liquid limit) versus compression index and coefficient of secondary compression.

Similar chart was established for hemic and sapric type of peat. Maximum reduction in $C c$ value with the corresponding value of length to diameter ratio $(\mathrm{l} / \mathrm{d})$ of each cement column is then plotted in Fig. 9. Based on this figure it shows that small $l / d$ ratio of cement column is effective in decreasing compression ratio value. This chart could be used as a design guide to select the effective dimension of cement column for deep soil mixing method in tropical peat soil. Effective $l / d$ ratio can be determined either by using the chart or from the given formula. For example for fibric soil with $75 \%$ organic content, based on Fig. 9, $C c$ of 1.6 is predicted. Using $60 \%$ of reduction in $C c$ value will give an improved value of 0.96 using cement column is predicted. Referring to Fig. 9 for desired $C c$ of 0.96 the effective $l / d$ ratio of 0.8 is needed.

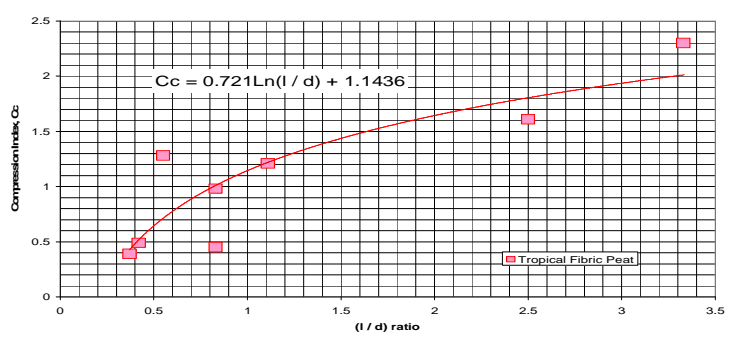

Fig. 9: Compression index versus $l / d$ ratio.

\section{CONCLUSION}

The following are the main observations drawn from the index test and consolidation test described in this paper:

1. Coefficient of secondary compression $(C \alpha)$ values of fibric, hemic and sapric of tropical peat are in the range of 0.08 to 0.09 . These values are indicative of soil with extremely high secondary compressibility.

2. Compression ratio $\left(C_{C} / 1+e_{o}\right)$ of fibric, hemic and sapric are in the range of 0.2 to 0.4 and classified as very compressible.

3. The $C \alpha / C c$ law value of fibric, hemic and sapric peat of tropical are in the range of $0.02-0.04$. It is smaller than the value 0.05 to 0.07 suggested by Mesri and Castro ${ }^{[5]}$.
4. Tropical fibric peat will cause highest settlements followed by hemic and sapric when subjected to any load over the time period.

5. Compression index of fibric sample was reduced by $60 \%$ using single cement column of $45 \mathrm{~mm}$ diameter and $80 \%$ with cement column of $60 \mathrm{~mm}$ diameter. Hence, it suggests that larger diameter cement column has a higher reduction effect in the compression index. The trend is similar in hemic and sapric peat.

6. A group of cement columns had a significant impact in reducing the compressibility parameters compared to a single cement column.

7. The influence of curing time on both the single and group cement columns in reducing the compressibility parameters are significant. Increasing curing time is found to be effective in compressibility control.

8. Compressibility parameters (compression index and coefficient of secondary compression) are significantly improved with cement column.

\section{RECOMMENDATIONS}

The current study is of laboratory scale and need to be extended to field study. Author is also interested to study the performances of cement column using various compositions such as lime and nontraditional admixtures. It would be useful to compare testing results from laboratory prepared specimens and field prepared specimens in a demonstration project.

\section{ACKNOWLEDGMENT}

Financial assistance from the Ministry of Science, Technology and Innovation Malaysia (MOSTI), as Research Grant to the supervisor and Scholarship from University Malaysia Pahang to the first author are gratefully acknowledged. A special tribute goes to Mrs. Ernaleza Mahsum (Research Assistant) for her industrious work in the laboratory and field.

\section{REFERENCES}

1. Jarret, P. M. 1995. Geoguide 6. Site Investigation for Organics Soils and Peat. JKR Document 207090341-95. Institut Kerja Raya Malaysia

2. Huat, B.B.K. 2004. Organic and Peat Soils Engineering. Universiti Putra Malaysia Press, Serdang

3. Mesri, G. 1973. Coefficient of secondary compression, J. Soil Mech. Found. Div, ASCE. Vol. 99, no. SMI

4. O'Loughlin, C. D. and B. M. Lehane. 2003. A study of the link between composition and compressibility of peat and organic soils. In Proceedings of 2 nd International Conference on Advances in Soft Soil Engineering and Technology, Putrajaya, Malaysia, ed. Huat et al. p 135-152

5. Mesri, G. and Castro, A. 1987. C $\alpha /$ Cc concept and Ko during secondary compression. Journal of Geotechnical Engineering, Vol. 123, p 230-247. 